\title{
Blood type A associates with critical COVID- 19 and death in a Swedish cohort
}

\author{
Michael Hultström ${ }^{1,2^{*}+}$ (D) Barbro Persson ${ }^{3+}$, Oskar Eriksson ${ }^{3}$, Miklos Lipcsey ${ }^{1}$, Robert Frithiof ${ }^{1+}$ and Bo Nilsson ${ }^{3+}$
}

To the editor,

Coronavirus disease 2019 (COVID-19) is primarily associated with respiratory failure, but both renal and circulatory failure is common in patients that require critical care or die of the disease [1]. A recently published GWAS showed a strong association between severe COVID-19 and the ABO blood group locus in a cohort from Italy and Spain, with a higher risk for patients with blood group A [2]. This is consistent with data on susceptibility to COVID-19 being associated with blood group in Chinese [3]. Although the GWAS dataset did not include data on mortality, there is a preliminary report in an American cohort that blood group A is associated with both severity of COVID-19 and death [4].

Here, we present data on blood type distribution from a Swedish critical care cohort $(n=64)$ compared to the blood type distribution in the population as a whole: A 43\%, AB 4\%, B 9\%, and O $44 \%$ giving a dichotomized distribution of $\mathrm{A} / \mathrm{AB} 47 \%$ to $\mathrm{B} / \mathrm{O} 53 \%$ [5]. Blood typing was performed using routine clinical procedures at the Clinical Immunology and Transfusion Medicine at the University Hospital in Uppsala.
Using the population blood type distribution to estimate the expected frequencies, we found an association of blood type $\mathrm{A}$ with the risk of requiring critical care $(\mathrm{HR}(95 \% \mathrm{CI})=2.01(1.23-3.28))$ and increased risk of death within 30 days $(\mathrm{HR}(95 \% \mathrm{CI})=$ 3.16 (1.28-7.77)) in COVID-19 (Fig. 1). This indicates that the findings in the previous studies are consistent also in a northern European population.

Although the present study does not investigate the mechanism behind the association, one potential mechanism that may be involved in the increased risk linked to blood type antigen $\mathrm{A}$ is that it contains a galactose as end group saccharide. Both blood type B and $\mathrm{O}$ have a galactose amine in this position, which may explain the difference between the blood groups. The spike protein of SARS-COV-2 has been shown to bind carbohydrates, and a strong affinity between the A antigen and the virus could facilitate uptake of the virus into the cells [6].

Limitations of the present dataset is a relatively low number of patients, which in this case goes with a difference in the average age of 63 years for the $\mathrm{A} / \mathrm{AB}$ group compared to 55 years for the $\mathrm{B} / \mathrm{O}$ group. In addition, there is a difference in sex distribution of $81 \%$ male in the $\mathrm{A} / \mathrm{AB}$ and $69 \%$ in the $\mathrm{B} / \mathrm{O}$. Both of these effects

\footnotetext{
* Correspondence: michael.hultstrom@mcb.uu.se

${ }^{+}$Michael Hultström and Barbro Persson have equal contribution as the first authors

${ }^{\dagger}$ Robert Frithiof and Bo Nilsson have equal contribution as the last authors ${ }^{1}$ Anesthesia and Intensive Care Medicine, Department of Surgical Sciences, Uppsala University, Uppsala, Sweden

${ }^{2}$ Integrative Physiology, Department of Medical Cell Biology, Uppsala University, Uppsala, Sweden

Full list of author information is available at the end of the article
} 


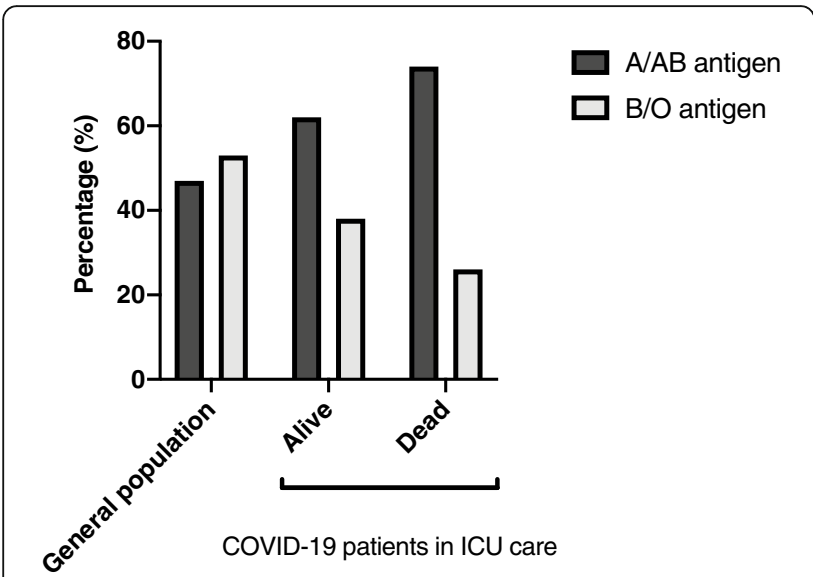

Fig. 1 Distribution of blood types $A / A B$ antigen and $B / O$ antigen in the Swedish population ( $A / A B$ 47\%, B/O 53\%) compared to intensive care patients who survived ( $n=45, \mathrm{~A} / \mathrm{AB} 62 \%, \mathrm{~B} / \mathrm{O} 38 \%)$ and who died ( $n=19, \mathrm{~A} / \mathrm{AB} 74 \%, \mathrm{~B} / \mathrm{O} 26 \%$ ) of COVID-19 at a tertiary care critical care facility in Sweden. Blood type $A / A B$ is associated with an increased risk of death: hazard ratio $(95 \% \mathrm{Cl})=3.16(1.28-7.77)$

would tend to lead to an overestimation of the effect of blood type $\mathrm{A} / \mathrm{AB}$ in the present dataset, which would tend to bring the results more in line with the previously published risk profile [6].

In conclusion, we show that blood type $A$ or $A B$ is associated with an increased risk of requiring critical care or dying of COVID-19 in the Swedish population. Taken together, with previously published data, this indicates that blood group A is a risk factor for disease severity and death in COVID-19 irrespective of the genetic background.

\section{Acknowledgements}

The authors thank research nurses Joanna Wessbergh and Elin Söderman and the biobank assistants Erik Danielsson and Philip Karlsson for their expertise in compiling the study.

\section{Authors' contributions}

All authors participated in the conception and design of the study. All authors had access to the data and participated in data collection and interpretation. $\mathrm{MH}$ drafted the manuscript, and all authors contributed to manuscript revision and gave approval of the final version.

\section{Funding}

The study was funded by the SciLifeLab/KAW National COVID-19 research program project grant to MH (KAW 2020.0182); the Swedish Research Council to RF (2014-02569 and 2014-07606), BN (2016-01060, 2020-05672), and OE (201506429); and the Swedish Heart-Lung Foundation to BN (HLF 2020-0398).

\section{Availability of data and materials}

Data in the current study is available from the corresponding author on a reasonable request.

\section{Ethics approval and consent to participate}

The presented data is part of a study approved by the National Ethical Review Agency (EPM; no. 2020-01623). Informed consent was obtained from the patient or next of kin if the patient was unable to give consent. The Declaration of Helsinki and its subsequent revisions were followed.

\section{Competing interests}

The authors declare that they have no conflicts of interest.

\section{Author details}

${ }^{1}$ Anesthesia and Intensive Care Medicine, Department of Surgical Sciences, Uppsala University, Uppsala, Sweden. ${ }^{2}$ Integrative Physiology, Department of Medical Cell Biology, Uppsala University, Uppsala, Sweden. ${ }^{3}$ Clinical

Chemistry, Department of Immunology, Genetics and Pathology, Uppsala, Sweden.

Received: 28 July 2020 Accepted: 3 August 2020

Published online: 12 August 2020

\section{References}

1. Chen T, Wu D, Chen H, Yan W, Yang D, Chen G, Ma K, Xu D, Yu H, Wang H, et al. Clinical characteristics of 113 deceased patients with coronavirus disease 2019: retrospective study. BMJ. 2020;368:m1091.

2. Ellinghaus $D$, Degenhardt $F$, Bujanda $L$, Buti $M$, Albillos $A$, Invernizzi $P$, Fernandez J, Prati D, Baselli G, Asselta R, et al. Genomewide association study of severe Covid-19 with respiratory failure. N Engl J Med. 2020.

3. Li J, Wang X, Chen J, Cai Y, Deng A, Yang M. Association between ABO blood groups and risk of SARS-CoV-2 pneumonia. Br J Haematol. 2020; 190(1):24-7

4. Zietz M, Tatonetti NP: Testing the association between blood type and COVID-19 infection, intubation, and death. medRxiv 2020. https://doi.org/10 1101/2020.04.08.20058073.

5. Reid ME, Lomas-Francis C, Olsson M: The blood group antigen facts book, 3 edn. San Diego: Elsevier Ltd.; 2012.

6. Chiodo F, Bruijns SCM, Rodriguez E, Li RJE, Molinaro A, Silipo A, Di Lorenzo F, Garcia-Rivera D, Valdes-Balbin Y, Verez-Bencomo V et al: Novel ACE2independent carbohydrate-binding of SARS-CoV-2 spike protein to host lectins and lung microbiota. bioRxiv 2020. https://doi.org/10.1101/2020.05. 13.092478.

\section{Publisher's Note}

Springer Nature remains neutral with regard to jurisdictional claims in published maps and institutional affiliations.
Ready to submit your research? Choose BMC and benefit from:

- fast, convenient online submission

- thorough peer review by experienced researchers in your field

- rapid publication on acceptance

- support for research data, including large and complex data types

- gold Open Access which fosters wider collaboration and increased citations

- maximum visibility for your research: over $100 \mathrm{M}$ website views per year

At BMC, research is always in progress.

Learn more biomedcentral.com/submissions 